\title{
PLANTATION FORESTS AS REGIONAL STRENGTH FOR DEVELOPMENT OF RURAL BIOECONOMY
}

\author{
Mudrite Daugaviete ${ }^{1}$, Dr.sc.ing.; Galina Telysheva ${ }^{2}$, Dr.habil.chem.; Ojars Polis ${ }^{3}$, Mg.chem. \\ Ausma Korica ${ }^{4}$, Mg.silv.; Kaspars Spalvis ${ }^{5}$, Mg.sc.ing. \\ $1,3,4,5$ Latvian State Forest Research institute 'Silava', Latvia \\ ${ }^{2}$ Latvian State Institute of Wood Chemistry, Latvia
}

\begin{abstract}
The establishment of plantation forests in areas not viable for agriculture can make a significant contribution to the economy. The yield from 1 ha of plantation forest depends on the management purpose obtaining of round wood (pulpwood, sawnlog, veneer log, tare), bioenergy and extraction of tree foliage (broadleaved and coniferous). In Latvia, based on 2019 data, plantation forests achieve 2760 ha of Scots pine, 7855 ha of Norway spruce, 7431 ha of Birch, 2123 ha of Grey alder, 1274 ha of Black alder and Populus spp. and 618 ha of Salix spp.

Estimated and projected gains are calculated both as round wood over 20 to 50 years: pine - 410-to 994 thou. $\mathrm{m}^{3}$; spruce, - 335 to 2.906 thou. $\mathrm{m}^{3}$, birch - $1.040-2.452$ thou. $\mathrm{m}^{3}$. Accordingly, it is possible to obtain gross income from the whole plantation forest area in Latvia: pine-12.42-63.8 mln. EUR; spruce - $40.1-192.3 \mathrm{mln}$. EUR; for birch - 32.2 -202.7 mln. Eur. Additionally to that, 18.6 -21.6 t ha-1 and 24.0 -37.0 t ha-1 of processed foliage can be obtained from 1 ha of pine and spruce forest plantations (40-50 years old). Alnus incana sp. (5-20 years), yielding 19.65-122.65 thou. Solid $\mathrm{m}^{3}$ and Salix spp. (3-5 years), yielding 58.71-84.97 thou. solid $\mathrm{m}^{3}$, are used for energy production, furthermore Alnus spp. wood can be used than valuable raw material for plywood production. At the same time, it is possible to capture 106-1477 thou. tonnes of $\mathrm{CO}_{2}$ equivalent. Systematic investigations of chemical composition of above mentioned Latvian plantation trees, wood and bark, have shown that incorporation of extraction treatment in existing processing schemes will allow to manufacture high value added monomeric and oligomeric products which are of great demand for substitution of synthetic ones in different economy sectors (agriculture, including means for plant protection, food industry, polymer production, pharmacy etc.). Creation of small and medium-sized enterprises in rural region in close proximity to plantations opens the opportunity for the appearance of new working places, including organization of new nurseries, plantation services, private businesses for processing of various lignocellulosic waste into new special products / semi-products / feedstock for green industrial materials and chemicals, at the same time diminishing the logistics expenses.
\end{abstract}

Key words: plantation forest, coniferous, deciduous species, productivity, biomass diversity, biomass extraction, socio-economic impact, net income, $\mathrm{CO}_{2}$

JEL code: R11

\section{Introduction}

The Sustainable Development Goals, the Paris Climate Agreement, the European Forest Process, as well as EU goals and policies, set new requirements for European forests. These include helping to mitigate climate change, provide goods and services, create jobs and act as a source of fuel and raw materials. The development of an innovative, sustainable bioeconomy is a key strategy and forestry is expected to play a major role in providing the raw materials and services needed in Europe. There is new evidence that sustainable management of plantations, especially as part of the landscape-scale mosaic, has great potential in the context of new European policy priorities. Scientific evidence on how best to achieve these goals while achieving multifunctionality and maximizing synergies between ecosystem services is key to the success of future forestry programs (Freer-Smith et al. 2015; Baunhus et al., 2011; Paguette and Messier, 2010; Payn et al., 2015, Botto et al., 2016).

Plantation forests can be defined as "forest or other wooded land with native or introduced tree species created by planting or sowing" (FAO, 2006). The importance of forest plantations is reflected in the "Forestry Principles" adopted by the United Nations Conference on Environment and Development (UNCED) in Brazil in 1992 and reiterates the importance of heavily managed forest 
plantations. Principle 6d states: "The importance of cultivated forests as a sustainable and environmentally friendly source of renewable energy and as industrial raw materials should be recognized, enhanced and promoted. Their contribution to maintaining ecological processes, relieving pressure on primary / natural forests and ensuring regional employment and development must be recognized and improved. (Keenan et al., 2015; Freer-Smith et al., 2019).

Plantation forest functions and services are diverse. For example, the FAO distinguishes between 'productive' and 'protective' plantations (Penna, 2010). Production plantations are mainly focused on the production of industrial wood, fuel wood and other wood products (animal fodder, beekeeping, essential oil, bark, cork, latex, food), while protected plantations are designed to provide conservation, recreation, carbon sequestration, water quality control, erosion control, and degradation of degraded lands, which also includes improving landscapes and landscaping (FreerSmith et al., 2019; Savill et al, 2009).

Plantation forestry is also shifting from large-scale monoculture to smaller-scale or medium-sized areas where local households and communities are owners or co-owners and are employed in plantation forest management (Freer-Smith et al. 2019). The forest areas planted in the former agricultural lands in Latvia are not large. A total of 48,547 ha of forest stands planted on agricultural land for 20 years (1999-2018), of which 21,231 h were declared as plantation forest. The data show that if forest stands were mostly planted at the beginning of the period (1999), only from 2015 plantation forest dominates over planted forest stands on former agriculture areas. State Forest Service data show that the most often planted tree species is spruce - $36 \%$, birch $-35 \%$, common pine $-13 \%$ of the total planted amount (Latvian Forest Sector in facts \& figures 2020, https://www.zm.gov.Iv/public/ck/files/ZM/mezhi/skaitlifakti_ENG20.pdf). Meanwhile, according to the Forest Monitoring and LVMI Silava research data, in the period 1993-2013 - about 233 thousand. ha of uncultivated agricultural land is naturally afforested (Lazdins, 2011). According to Rural Support Service Republic of Latvia data, as of 1 October 2019, untreated agricultural land in Latvia still constituted 256179.66 ha (http://www.lad.gov.lv/lv/atbalsta-veidi/noderigi /lauksaimnieciba-izmantojamas-zemes-apsekosana-1/).

Based on MEA (2005) and scientists, ecosystem services and services are grouped here in four main categories: Production functions; Regulatory functions; Recreational functions; Ecosystem services; Ecological assessment (https://www.millenniumassessment.org/en/index.html; de Groot et al., 2002).

On 20 December 2012, the National Development Plan of Latvia 2014-2020 was adopted, which requires the rational use of land (Latvian National Development Plan, 2012). The Latvian State Land Service (SLS) is developing guidelines for land use policy in Latvia. This document defines its objectives, directions and ways of achieving these objectives (http://www.varam.gov.lv /in_site/tools/download.php?file=files/text/Sab_lidzdaliba/sab_apsp//VARAM_Zemes_politikas_plan s_211116.pdf). The document states, that "measures and incentives should be developed for the afforestation, ecological and landscaping of non-farm lands, contributing to the preservation of traditional rural landscapes", as well as forestry, tourism etc. Currently, the National Development Plan of Latvia for 2021-2027 is being updated, where one of the priority measures is to raise the standard of living and quality of population by increasing employment and income" (https://www.pkc.gov.Iv/en/aktualit\%C4\%81tes/expert-groups-have-initiated-nationaldevelopment-plan-2021-2027-year-detailed). 
Research on plantation forest and tree planting possibilities in unmanaged agricultural lands in Latvia is still ongoing (Daugaviete et al., 2017). Scientists are studying optimal growing conditions for different tree plantations (Pinus spp., Picea spp., Betula spp., Populus spp., Alnus spp., Salix spp.), methods for plantation establishment and subsequent productive management (Lazdina \& Daugaviete, 2010; Daugaviete et al., 2017).

Long-term studies show that the selection of suitable soil for planting forest, short rotation plantations of relevant tree species (Pinus spp., Picea spp., Birch spp., Populus spp., Alnus spp., Salix spp.) significant benefits in the short term- both economically and ecologically (Lazdins, 2011; Daugaviete, et al., 2017).

Current paper reflects results of potential incomes from production function.

Research objective is to identify and evaluate the value and benefits of short-rotation plantations and plantation forests on different soil types for Latvian rural development and possibility to obtain high value-added products by integration of extraction as an intermediate additional unit into production of final fuel wood.

\section{Materials and methods}

Plantation productivity - yield, output (pulpwood, sawdust, veneer log, tare log, woodchip, etc.) was calculated both by plantation survey and pronation of plantation stock up to management target output (Lazdina \& Daugaviete, 2010; Daugaviete et al., 2017).

Estimation of income from establishment, management and production of short-rotation tree plantations and plantation forests to assess potential economic benefits. Data from the Central Statistical Bureau database (www.csp.gov.lv) have been used. Carbon content in wood is assumed to be $50 \%$ on average according to good practice guidelines for the calculation of $\mathrm{CO}_{2}$ capture and GHG emissions in land use, land use change and forestry (Liepins, 2020). The conversion of carbon (C) storage to $\mathrm{CO} 2$ has been made by multiplying $\mathrm{C}$ tonnes by 44 and dividing the result by 12 (Lazdins, 2012, Liepins, 2020).

Qualitative and quantitative liquid chromatography alongside with complex of physical-chemical and wet chemistry methods were used as tools which allowed to evaluate potential of the Latvian plantation trees (in particular, deciduous trees as black \& grey alder, willow) as a source of high value added biologically active compounds (Telysheva et al. 2018, Lauberte et al. 2017, Janceva et al. 2017, Ponomarenko et al. 2014, Lauberts et al. 2018).

\section{Research results and discussion \\ 1. Productivity and potential economic income}

Forecasting the sustainable development of plantation forests and their benefits for the Latvian economy, the survey of the first 20 years, current research results and current norms for forest taxation in the Republic of Latvia have been taken into account (Daugaviete et al., 2017).

Studies show that the growth rate of the most common tree species planted on agricultural land in young plantations corresponds to the Ia site index parameters, therefore in future forecasts Ia site index data were taken in pine, spruce, birch, black alder and grey alder stands (Daugavietis et al. 2013; Donis, 2014). Forecasts show that the management of plantations of the most common tree species in Latvia (pine, spruce, birch, grey alder, black alder) can result in a significant increase in wood yielding significant current assets for the economy (Table 1 ). 
Potential wood stock from plantation forests, $\mathbf{m}^{3}$

\begin{tabular}{|c|c|c|c|c|c|}
\hline \multirow{2}{*}{ Tree species } & \multirow{2}{*}{$\begin{array}{c}\text { Area of } \\
\text { plantations, ha }\end{array}$} & \multicolumn{4}{|c|}{ Growing stock, $\mathrm{m}^{3} \cdot \mathrm{ha}^{-1} /$ thou. $\mathrm{m}^{3}\left(\mathrm{~m}^{3} *\right.$ area $\left.^{-1}\right)$} \\
\hline & & $\begin{array}{l}\text { During } \\
20 \text { years }\end{array}$ & $\begin{array}{l}\text { During } \\
30 \text { years }\end{array}$ & $\begin{array}{l}\text { During } \\
40 \text { years }\end{array}$ & $\begin{array}{l}\text { During } \\
50 \text { years }\end{array}$ \\
\hline Pine & 2760 & $150 / 410$ & $240 / 662$ & $310 / 856$ & $360 / 994$ \\
\hline Spruce & 7855 & $170 / 1335$ & $250 / 1964$ & $300 / 2356$ & $370 / 2906$ \\
\hline Birch & 7431 & $140 / 1040$ & $200 / 1486$ & $250 / 1858$ & $330 / 2452$ \\
\hline Grey alder & 2123 & $150 / 319$ & $240 / 509$ & - & - \\
\hline Black alder & 1274 & $170 / 217$ & $240 / 306$ & $300 / 382$ & $330 / 420$ \\
\hline
\end{tabular}

Estimated revenue is calculated by taking into account the distribution of extracted wood according to the wood and assortments (Lipins \& Liepa, 2007) as well as the average (2016-2018) prices of timber (https://www.csb.gov.Iv/lv/statistika/statistikas-temas/lauksaimnieciba /mezsaimnieciba/meklet-tema/2616-apalo-kokmaterialu-videjas-iepirkuma-cenas; http://latkoks.Iv/?page_id=2927).

Estimated gross revenue from plantation forests (NPV), mIn. EUR

\begin{tabular}{|c|c|c|c|c|}
\hline \multirow{2}{*}{ Tree species } & \multicolumn{4}{|c|}{ Estimated revenue, Eur.ha ${ }^{-1}$ / Total revenue EUR mIn. EUR } \\
\hline & During 20 years* & During 30 years** & $\begin{array}{l}\text { During } \\
40 \text { years } * * *\end{array}$ & $\begin{array}{l}\text { During } \\
50 \text { years } * * * *\end{array}$ \\
\hline Pine & $4500 / 12.42$ & $7488 / 20.7$ & $19401 / 53.5$ & $23102 / 63.8$ \\
\hline Spruce & $5100 / 40.1$ & $10143 / 79.7$ & $19489 / 153.1$ & $24487 / 192.3$ \\
\hline Birch & $4340 / 32.2$ & $7650 / 56.8$ & $11500 / 85.5$ & $27281 / 202.7$ \\
\hline Grey alder & $3975 / 8.4$ & $7291 / 15.5$ & - & - \\
\hline Black alder & $4505 / 5.7$ & $7180 / 9.1$ & $10466 / 13.3$ & $12198 / 15.5$ \\
\hline \multicolumn{5}{|c|}{ 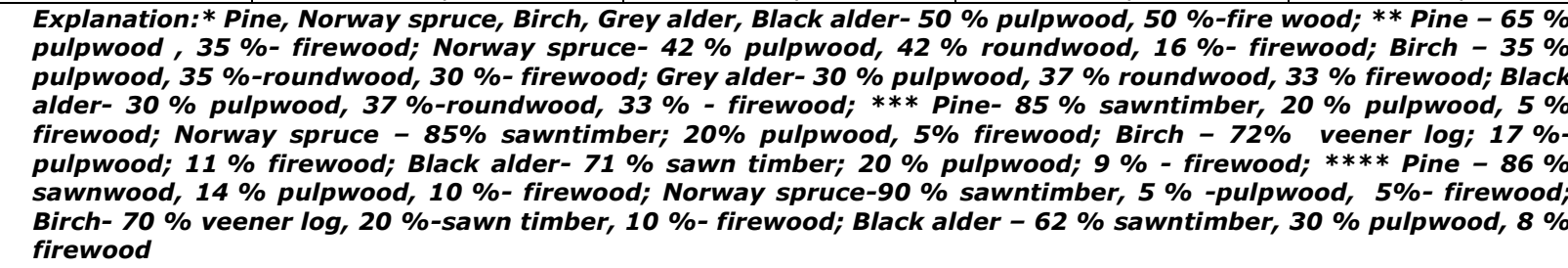 } \\
\hline
\end{tabular}

As Table 2 shows, plantation forestry is a significant source of income and employment. Expected income for the first 20 years of management (in the form of felling stock) is for spruce plantations, followed by pine, black alder and birch plantations. In later years, 30-40-year-old plantations can be marked as the most productive spruce and birch plantations, because it is possible to obtain both high quality logs and plywood for the production of plywood. Table 2 also estimates the income for 50 -year-old plantations, but it is likely that only pines will grow until the age of 50, as yield and income growth is only $8 \%$ compared to 40 -year-old pine plantations. Birch plantations show the highest revenue growth in calculations, but this is achieved with the cost of Class A plywood blocks, as the difference in price per $\mathrm{m}^{3}$ of Class $A$ and Class $B$ plywood shows a $60 \%$ increase.

\section{Short rotation plantations and tree plantations to provide renewable resources}

The contribution that can be gained from short-rotation plantations and tree agriculture practice management (Law on Agriculture and Rural Development, in force since 16 October 2014) is essential 
for the provision of renewable energy. The most promising tree species: osier, willow (Salix spp.), Grey alder (Alnus spp.), Poplar (Populus spp.), Hybrid aspen (Populus hybrids).

The management of grey alder stands for the production of woody biomass occupies an important place in Latvia. Analysis of the growth of grey alder stands shows that grey alder is suitable for the production of woody biomass in short rotation plantations (Daugaviete et al. 2017). Studies have shown that in 5-20-year-old white alder forest stands it is possible to obtain an average of $47-$ 286 solid $\mathrm{m}^{3} \mathrm{ha}^{-1}$.

Between 1999 and 2018, 2123 ha of grey alder afforested or formerly naturally afforested agricultural land were declared as plantations. Currently, willow plantation management is expanding in Latvia as well (Lazdins, 2011; Lazdina\&Daugaviete, 2010; https://www.zemeunvalsts.Iv/karkliresursi-plantacija-iespejas). 618 ha of willow plantations are officially registered in Latvia. When calculating the resources and income of willow and grey alder plantations, it must be concluded that it is necessary to increase the area of willow as well as to manage grey alder in forest areas as potential biomass producers (Table 3 ).

Table 3

Short rotation plantation resource and revenue forecasts, $\mathrm{m}^{3}$, thou. EUR

\begin{tabular}{|l|c|c|}
\hline & $\begin{array}{c}\text { Willow plantation rotation } \\
\mathbf{3 - 5} \text { years }\end{array}$ & $\begin{array}{c}\text { Grey alder plantations } \\
\text { (5-20 years) }\end{array}$ \\
\hline Area to be developed, ha & 618 & 2123 \\
\hline Obtained biomass t ha-1 & $28.50-41.25$ & $14.82-92.43$ \\
\hline $\begin{array}{l}\text { Potential biomass yield, thou. t } \\
\text { plantation area }\end{array}$ & $17.61-25.49$ & $31.46-196.23$ \\
\hline $\begin{array}{l}\text { Potentially obtained thou., solid } \\
\text { m }^{3} \text { plantation area }\end{array}$ & $58.71-84.97$ & $19.65-122.65$ \\
\hline Revenue, EUR ha-1 $^{-1}$ & $906-1310$ & $470-1174$ \\
\hline * Revenue, thou. EUR area-1 & $560-810$ & $998-2492$ \\
\hline
\end{tabular}

\section{Production of non-wood products}

One of the benefits of plantation forests is the use of non-wood products. The big impact in this field in Latvia was made by manufacture of valuable products by extraction of biologically active compounds from the foliage of coniferous trees and working out and manufacture on its basis of new valuable products (Daugavietis, 2013; Polis \& Spalvis, 2013). Studies on the amount of conifer green foliage show that $100 \pm 20 \mathrm{~kg}$ of spruce foliage and $80 \pm 10 \mathrm{~kg}$ of pine foliage can be obtained per $\mathrm{m}^{3}$ of wood (Daugavietis, 2013; Daugaviete \& Korica, 2013; Polis\&Spalvis, 2013), the processing of which into valuable ecological products (www.biolat.lv) can make a significant contribution to the economy (Table 4).

Besides the foliage, unique composition of bark biomass allows to obtain numerous value-added products (individual compounds and mixtures of synergetic activity) that allows to consider tree bark as the classic object for biorefinery. The yield of bark varies from 2-4 \% up to $10-12 \%$ and more from the total tree biomass (depending on tree species and age) that makes the bark very promising resource for technological processing.

The lack of knowledge about composition, properties of biomass to be extracted and extractoriented efficiency of green solvents to be used according to current safety requirements as well as necessity to improve existing extraction devices efficiency underpin modern investigations all over the world. In our case, the microwave assisted extractor of original design allowed to obtain promising results for the mentioned purposes at the decreased consumption of energy, solvents and 
duration of process. After full extraction cycle bark residues could be used for bio-pellets production with improved calorific properties (Arshanitsa et al. 2016, Janceva et al. 2017).

Currently, on the basis of investigations of the Latvian deciduous plantation tree bark, different products for industry, agriculture and human health are developed. Among them, there are effective antioxidants, food supplements, cosmetic creams, including sun protection means, adhesives for wood particle boards, hydroxyl-rich polymer building blocks for polymers synthesis and polyurethane composite materials for thermoinsulation, fuel pellets, which all meet the requirements of EU standards (Telysheva et al. 2018, Arshanitsa et al. 2010, Andersone et al. 2018). Even more species are suitable for obtaining of specific compound groups, and individual compounds, in particularly Salix for salicin and proanthocyanidins and alder bark for diarylheptanoids and proanthocyanidins.

On the basis of oregonin-rich extract from alder, the food-supplement "Orvital" was produced as a commercial product (three cosmetic creams were produced and sold through pharmacies (registered in the Latvian food and veterinary service).

For realization of opportunities that are opened at the processing of bark in the context of biorefinery, cooperative net of SME engaged in processing is necessary. Whereas plantations could be considered as bioeconomy key points: drivers, primary feedstock suppliers, and in some case consumers (of the means necessary for plant healthening).

Studies on the amount of conifer green foliage show that $100 \pm 20 \mathrm{~kg}$ of spruce foliage and 80 $\pm 10 \mathrm{~kg}$ of pine foliage can be obtained per $\mathrm{m}^{3}$ of yield (Daugavietis, 2013; Daugaviete \& Korica, 2013; Polis\&Spalvis, 2013), the processing of which into valuable ecological products (www.biolat.Iv) can make a significant contribution to the economy (Table 4).

Table 4

Estimated revenue from coniferous green foliage use in plantation forests

\begin{tabular}{|c|c|c|}
\hline & \multicolumn{2}{|c|}{ Tree species } \\
\hline & Pine & Spruce \\
\hline Area to be developed, ha & 2760 & 7855 \\
\hline Harvested stocks (40-50-year.) $\mathrm{m}^{3} \mathrm{ha}^{-1}$ & $310-360$ & $300-370$ \\
\hline Green biomass obtained from $1 \mathbf{~ m}^{3}$ timber, $\mathbf{k g}$ & $50-60$ & $80-100$ \\
\hline Green biomass obtained from 1 ha, $t$ & $18.6-21.6$ & $24.0-37.0$ \\
\hline Revenue from 1 t of processed lingon products, EUR & 2000 & 910 \\
\hline Estimated income from 1 ha plantation, thou. EUR ha-1 & $37.2-43.2$ & $21.8-33.7$ \\
\hline Estimated income from plantation area, $\mathrm{mln}$. EUR & $102.7-119.2$ & $171.2-264.7$ \\
\hline
\end{tabular}

\section{Greenhouse effect mitigation options}

During the climate change period, the amount of carbon dioxide captured by plantation forests is an important contribution, thus reducing the greenhouse effect in the atmosphere (https://lzj.Iv/en/sildumnicas-effekts; Lazdins, 2012; Liepins, 2020). In sustainably managed forests, carbon accumulation never stops, as new trees replace felled trees. In the felled tree, carbon is still attached - as a "storage" of carbon. Young stands attract $\mathrm{CO}_{2}$ very strongly and use it for growth (Lazdins, 2012; Jansons, 2017; Daugaviete et al., 2008; Liepins, 2020).

In the forests managed by LVM (Latvian State Forests), every year the forests attracts 4.1 million. tons of carbon or $15 \mathrm{mln}$. tons of $\mathrm{CO}_{2}$ eq., but the total storage in living biomass or in all forests managed by LSF (Latvian State Forests) is $123 \mathrm{mln}$. tons of carbon or $450 \mathrm{mln}$. tons of $\mathrm{CO}_{2}$ eq. (The conversion factor for emissions from carbon to carbon dioxide is 3.67) (Lazdins, 2012) 
LSFRI Silava scientist J. Liepins (2020) has carried out extensive literature analysis, evaluating the results of 31 scientific studies from around the world on changes in carbon content between different regions, conifers and deciduous groups and concluded that regardless of climatic region the carbon content of conifers $(50.8 \pm 0.7) \%)$ is significantly higher in wood than in deciduous trees $(47.7 \pm 0.3 \%)$. When evaluating the data, it is recommended that, since there is still no conclusive data on the wood carbon content to be used in the hemiboreal forest zone, mean values for coniferous and deciduous trees are most stable, $50.8 \pm 0.6 \%$ and $48.8 \pm 0.6 \%$, respectively, Thomas \& A.R. Martin (2012) recommends moderate and boreal band.

Estimated amount of carbon sequestered in plantation forests, thou, $\mathrm{t} \mathrm{CO}_{2}$ equivalent

\begin{tabular}{|l|c|c|c|c|c|}
\hline \multirow{2}{*}{ Tree species } & \multirow{2}{*}{$\begin{array}{c}\text { Area of } \\
\text { plantations, ha }\end{array}$} & \multicolumn{4}{|c|}{${\text { CO } \mathbf{~ t} / \mathbf{h a}^{-\mathbf{1}}, \mathbf{t} * \mathbf{a r e a}^{-\mathbf{1}}}^{*}$} \\
\cline { 3 - 6 } & & $\begin{array}{c}\text { During } \\
\mathbf{2 0} \text { years }\end{array}$ & $\begin{array}{c}\text { During } \\
\mathbf{3 0} \text { years }\end{array}$ & $\begin{array}{c}\text { During } \\
\mathbf{4 0} \text { years }\end{array}$ & $\begin{array}{c}\text { During } \\
\mathbf{5 0} \text { years }\end{array}$ \\
\hline Pine & 2760 & $76 / 210$ & $122 / 337$ & $157 / 435$ & $183 / 505$ \\
\hline Spruce & 7855 & $86 / 675$ & $127 / 998$ & $152 / 1193$ & $188 / 1477$ \\
\hline Birch & 7431 & $68 / 505$ & $98 / 728$ & $122 / 906$ & $161 / 1196$ \\
\hline Grey alder & 2123 & $73 / 155$ & $117 / 248$ & - & - \\
\hline Black alder & 1274 & $83 / 106$ & $117 / 149$ & $146 / 186$ & $161 / 205$ \\
\hline
\end{tabular}

According to the data of Table 5, the relatively small amount of plantation forests in Latvia is capable of attracting a relatively large amount of $\mathrm{CO}_{2}$ and varies from 106 thou. $\mathrm{CO}_{2}$ equivalent up to $1.48 \mathrm{mln}$. $\mathrm{CO}_{2}$ equivalent.

\section{Conclusions, proposals, recommendations}

1) The establishment of plantation forests in areas, which are not viable for agriculture can make a significant economic contribution to the economy. The yield from 1 ha of plantation forest depends on the management purpose - extraction of roundwood (pulpwood, sawlog, veneer log, tare) or biomass (energy wood).

2) The yield of pine plantations during the forest management period of 20-50 years at the forecasted volume (150-360 $\mathrm{m}^{3} \mathrm{ha}^{-1}$ ) amounts to 4.5 (20 years) to 23.1 (50 years) thou. EUR ha-1 or at the existing plantation area (2760 ha) $-12.42-63.8 \mathrm{mln}$. EUR.

3) The yield from spruce plantations in the forest management period 20-50 years at the forecasted volume (170-370 $\mathrm{m}^{3} \mathrm{ha}^{-1}$ ) amounts to 5.1 (20 years) to 24.5 (50 years) thou. EURha-1 or at the existing plantation area (7855 ha) $-40.1-192.3 \mathrm{mln}$. EUR.

4) The yield from birch plantations during the forest management period 20-50 years at the forecasted volume (140-340 $\mathrm{m}^{3} \mathrm{ha}^{-1}$ ) amounts to 4.3 (20 years) to 27.3 (50 years) thou. EUR ha-1 or at the existing plantation area (7431 ha) - $32.2-202.7 \mathrm{mln}$. EUR.

5) Benefit from Grey alder short-rotation plantations for energy wood production with 5-20 year circulation is $14.82-92.43 \mathrm{t} \mathrm{ha}^{-1}$, potential yield biomass at existing plantation area (2123 ha) is $19.65-122.65$ thou. solidm ${ }^{3}$ or $998-2,492$ thou. EUR, respectively.

6 ) The yield from short-rotation plantations of willow (Salix spp.) for energy wood production with 3-5 year circulation is 28.5-41.25 $\mathrm{t} \mathrm{ha}^{-1}$, the potential biomass at existing plantation area (618 ha) is 58.71-84.97 thou. $\mathrm{m}^{3}$ or in cash $560-810$ thou. EUR, respectively.

7) Results of hardwood bark obtained from fast growing trees showed good prospects for integration of extraction cluster into existing streams of fast growing hardwood tree biomass biorefinery. 
8) From 1 ha of pine and spruce plantation forest (40-50 years old) it is possible to obtain 18.6$21.6 \mathrm{t} \mathrm{ha}^{-1}$ and $24.0-37.0 \mathrm{t} \mathrm{ha}^{-1}$ of green foliage respectively; from $1 \mathrm{t}$ foliage processing it is possible to obtain production for 2000 EURt $^{-1}$ and 910 EUR t$^{-1}$, gross income reaches $37.2-43.2$ thou. EUR ha-1 and 21.8 -33.7 thou. EUR ha-1, gross income 102.7 to $119.2 \mathrm{mln}$. EUR and 171.2$264.7 \mathrm{mln}$. EUR. of the whole plantation area, respectively.

9) The projected amount of carbon leakage in existing plantation forests is calculated from 106 thou. $\mathrm{t} \mathrm{CO}_{2}$ equivalent up to 1.477 thou. $\mathrm{t} \mathrm{CO}_{2}$ equivalent with a 20-50 year plantation cycle.

\section{Acknowledgement}

This paper is synthesis of MAGIC and BE-Rural results- projects received funding from the European Union's Horizon 2020 Research and Innovation programme under grant agreements No 727698 , No 818478E, ERDF project No. 1.1.1.1/18/A/182 and LS IWC Bioeconomy grant "LignoBark".

\section{Bibliography}

1. Andersone, A., Arshanitsa, A., Solodovnik, V., Kampars, V. (2018). Pelletizing of Bark Residue Resulting from Debarking of Softwood Trees. Key Engineering Materials, 2018, 762, pp.115-120.

2. Arshanitsa, A., Akishin, Y., Zile, E., Dizhbite, T., Solodovniks, V., Telysheva, G. (2016). Microwave treatment combined with conventional heating of plant biomass pellets in a rotated reactor as a high rate process for solid biofuel manufacture. Renewable Energy (91), 2016, pp. 386-396.

3. Arshanica, A., Barmina, I., Andersone, A., Telysheva, G., Zake, M. (2010). Processing and Complex Research of the Main Characteristics of Pelletized Lignocellulosic Materials for Clean and Effective Energy Production. International Scientific Colloquium "Modelling for Material Processing", Riga, September 16-17, 2010, pp. 151155

4. Baunhus, J., Meer, P., J. and Knninen, M. (Edit.). (2010). Ecosystem Goods and Services from Plantation Forests. 2010. EARTHCCAN, London, Washington, 274 p.

5. Botto, L, Pettenella, D, Cerutti, P and Pirard, R. (2016). Planted Forests in Emerging Economies: Best Practices for Sustainable and Responsible Investments. Occasional Paper 151. Bogor, Indonesia. Retrieved: https://www.cifor.org/publications/pdf_files/OccPapers/OP-151.pdf .Access: 30.04.2020.

6. Daugaviete, M., Bambe, B., Lazdinš, A. and Lazdina, D. (2017). Growth and Productivity of Plantation Forests. LSFRI Silava, p. 462. (In Latvian).

7. Daugaviete, M., Gaitnieks, T., Klavina, D., un Teliševa, G. (2008). Carbon Accumulation in the Above-Ground and Root Biomass of Pine, Birch and Spruce Cultivated in Agricultural Soils. Mezzinātne 18, 35-52. (In Latvian).

8. Daugaviete, M. and Korica, A. (2013). The Impact of Tree Foilage Utilization on Mineral Substance Turnover in Forest Ecosystems. Conference Proceedings. 13th International Multidisciplinary Scientific Geoconference SGEM 2013 16-22 June, Albena Co., Bulgaria: pp.797-800.

9. Daugaviete, M., Lazdins, A., Lazdina, D., Makovskis, K. and Daugavietis, U. (2017). Growth and Yield of 15Year Plantations of Pine, Spruce and Birch in Agricultural Land. Rural Sustainability Research 37(332), 2017, 38-50 pp.

10. Daugavietis, M. (2013). Latvia Experience: Potential for Tree Nonwood Biomass Utilization.13th SGEM Geo Conference on Water Resources, Forest, Marine and Ocean Ecosystem. Conference proceedings vol. 1, 353$360 \mathrm{pp}$.

11. Donis, J. (2014)..Improved Site Index Scales for the Most Important Forest Species in Latvia. In. „Four Motives of Forest Science" LVMI Silava: 13-36. (In Latvian).

12. Freer-Smith, P., Muys, B., Bozzano, M., DRossler, L.,Farrelly, N., Jactel, H., Korhonen, J., Minotta, G., Nijnik, M. and Orazio, Ch. (2019). Plantation Forests in Europe: Challenges and Opportunities. Form Science to Policy 9. European Forest Institute, Retrieved: https://doi.org/10.36333/fs09. Access: 30.04.2020.

13. de Groot, R., Wilson, M. and Boumans, M. (2002). A Typology for the Classification Description and Valuation of Ecosystem Functions, Goods and Services. February 2002, Ecological Economics 41(3): pp. 393-408.

14. Jansons, A. (Project Manager) (2017). Assessment of Greenhouse Gas Emission and CO2 Sequestration in Old Forest Stands. LVMI Silavap. 46 (In Latvian).

15. Janceva S., Lauberte L., Dizhbite T., Krasilnikova J., Telysheva G., Dzenis M. Protective Effects of Proanthocyanidins Extracts from Bark of Deciduous Trees in Lipid Systems. Holzforschung, Vol. 71, Issue 78, 2017.

16. Janceva, S., Lauberte, L., Arshanitsa, A., Akishin, J., Dizbite, T., Telysheva, G. (2018). Optimization of Proanthocyanidins Extraction from Bark of Local Hardwood Key Engineering Materials, 2018, Vol.762, pp.163168. 
17. Kenan, R.J., Reams, G.A., Achard, F., Freitas, J.V., Grainger, A. and Lindquist, E. (2015). Dynamics of Global Forest Area: Results from the FAO Global Forest Resources Assessment 2015. Forest Ecology and Management, Volume 352, pp. 9 -20.

18. Latvian Forest in Sector 2020. https://www.zm.gov.Iv/public/ck/files/ZM/mezhi/skaitlifakti_ENG20.pdf; Access: 30.04.2020.

19. Lauberte, L., Telysheva, G., Lauberts, M., Ikkere, L. E., Dizhbite, T., Viksna, A. (2017). Characterisation of Polyphenols in Different Varieties of Salix Bark. Latvijas Universitātes 75.starptautiskā conference. Kīmijas sekcija. Pp. 46.Ipp.

20. Lauberts, M., Lauberte, L., Arshanitsa, A., Dizhbite, T., Dobele, G., Bikovens, O., Telysheva, G. (2018). Structural transformations of wood and cereal biomass components induced by microwave assisted torrefaction with emphasis on extractable value chemicals obtaining. Journal of Analytical and Applied Pyrolysis 134, 2018, pp. 1-11.

21. Lauberts, M., Telysheva, G., Venskutonis, P.R., Lauberte, L., Dizhbite, T., Kazernavičiūte, R., Pukalskas, A. (2017). Diarylheptanoid-rich extract of grey and black alder barks: an effective dietary antioxidant in mayonnaise. Chemical Papers, 2017, 71, 1007 - 1012. doi:10.1007/s11696-016-0017-3.

22. Lazdina, D. and Daugaviete, M. (2010). Short Rotation Woody Energy Crops in Latvia. Fifth International Scientific Conference "Students on their way to science", Collection of abstracts, Jelgava, 2010:30-40.

23. Lazdins, A. (2011). Preconditions for Efficient Management of Naturally Afforested Farmlands. Summary of the Doctoral Thesis for the Scientific Degree Dr. in Forest Ecology and Silviculture. Jelgava: p. 50.

24. Lazdins, A. (proj. vad.) (2012). Development of a Reference Model for Calculating the Reference Level of Carbon dioxide (CO2) Sequestration and Greenhouse Gas (GHG) Emissions Caused by Latvian Forest Management. Rewiev, LSFRI Silava, p. 42 (In Latvian).

25. Liepins, J. (2020). Forest Stand Biomass and Carbon Stock Estimates in Latvia. Latvijas Vegetacija 30: 1114. (In Latvian).

26. Lipins L. and Liepa I. Measurement of Round Wood. LAU Forest Faculty. Monograph. Jelgava, 2007. P. 104 (In Latvian).

27. Millenium Ecosystem Assessment. Retrieved: https://www.millenniumassessment.org/en/index.html ; Access: 30.04 .2020$.

28. Paquette, A. and Messier, C. (2010). The Role of Plantations in Managing the World's Forests in the Anthropocene. Front Ecol Environ 2010; 8(1): pp.27-34.

29. Pawson, S.M., Brin, A., Brockerhoff , E. G., Lamb, D., Payn, T.W., Paquette, A. and Parrotta, J.A. (2013). Plantation Forests, Climate Change and Biodiversity. Biodivers Conserv (2013) 22:1203-1227.

30. Payn, F., Carnus, J.M., Freer-Smith, P, Kimberley, M., Kollert, W., Liu, Sh., Orazio, Sh., Rodriguez, L., Silva, L.N., and Wingfield, M.J. (2015). Changes in Planted Forests and Future Global Implications. Forest Ecology and Management, Volume 352, pp. 57-67

31. Penna, I. (2010). Understanding the FAO's 'Wood Supply from Planted Forests' Projections. University of Ballarat Centre for Environmental Management. Monograph Series No. 2010/0, p. 91(Retrieved: http://www.fao.org/forestry/42642-0aad8396ff459da7a9accf941e567ebb5.pdf).Access: 30.04.2020.

32. Polis, O. and Spalvis, K. (2013). Using Value of Tree Foliage in Latvia. (Conference Paper). 13th International Multidisciplinary Scientific Geoconference and EXPO, SGEM 2013; Albena; Bulgaria; 16 June 2013 through 22 June 2013; Code 102053. International Multidisciplinary Scientific GeoConference Surveying Geology and Mining Ecology Management, SGEM, pp 805-811.

33. Ponomarenko, J., Trouillas, P., Martin, N., Dizhbite, T., Krasilnikova, J., Telysheva, G. (2014). Elucidation of Antioxidant Properties of Wood Bark Derived Saturated Diarylheptanoids: A comprehensive (DFT-supported) Understanding. Phytochemistry, -2014, v.103, pp. 178-187.

34. Savill, P., Kerr, G. and Kotar, M. (2009). Future Prospects for the Production of Timber from Valuable Broadleaves. In book: Spiecker, H., Hedin, S., Makkonen-Spiecker, K. and Thies, M. (2009). Valuable Broadleaved Forests in Europe. EFI., Leiden.Boston:pp. 13-26.

35. Telisheva, G., Dizbite, T., Lauberte, L., Arshanica A., Lauberts, M., Janceva, S., Ponomarenko, J., Krasilnikova, J., Jashina, L., Andersone, A., Bikovens, O., Vevere, L.Akishins, J. (2018). Potentialities of Biorefeniry for Latvian Deciduous Tree Research of Forest and Earth Resources, Sustainable Use - New Products and Technologies (ResProd): National Research Programm, 2014 - 2018 : Proceedings / Latvian State Institute of Wood Chemistry . Rīga, 2018, 137-141. (In Latvian).

36. Thomas, S.C., and Martin, A.R. (2012). Carbon Content of Tree Tissues: A Synthesis. Forests 3(2): $332-352$. Retrieved: http://doi.org/10.3390/f3020332. Access: 303.04.2020. 